\title{
Vitamin D status in a representative sample of Irish adults aged $\geq 18$ years
}

\author{
S. Muldowney ${ }^{1}$, E. Walsh ${ }^{1}$, J. Walton ${ }^{1}$, B. McNulty ${ }^{2}$, A. Nugent $^{2}$, M. J. Gibney ${ }^{2}$, A. Flynn ${ }^{1}$ \\ and K. D. Cashman ${ }^{1,3}$ \\ ${ }^{1}$ School of Food and Nutritional Sciences and ${ }^{2}$ Department of Medicine, University College Cork, Cork, Republic of \\ Ireland, and ${ }^{3}$ Institute for Food and Health, University College Dublin, Dublin, Republic of Ireland
}

Recent data on vitamin D status in Ireland is limited to convenience samples ${ }^{(1-3)}$. The objective of this study was to evaluate vitamin D status in a more representative sample of Irish adults aged $\geq 18$ years. Analysis was based on a sub-sample $(n 519)$ of the National Adult Nutrition Survey of adults aged $\geq 18$ years, which is still ongoing. Serum 25 -hydroxyvitamin D $(25(\mathrm{OH}) \mathrm{D})$ concentration was measured in 249 men and 270 women using an ELISA method. Given that Ireland is at $51-55^{\circ} \mathrm{N}$, ultraviolet blue radiation from the sun is insufficient to stimulate dermal synthesis of vitamin D between November and March $^{(4)}$, and so we nominated November-March as winter and April-October as summer.

Gender (female, 52\%) and season (winter, $49 \%$ ) were evenly distributed in this sub-sample, whereas most subjects donated a fasting blood sample $(76 \%)$ and were from Munster (74\%). Median (Interquartile range) serum 25(OH)D concentration was 55.8 (41.6-72.2) $\mathrm{nmol} / \mathrm{l}$ for the sub-sample, with significant differences $(P<0.0001)$ between winter $(48.9$ [37.5-65.2] nmol/l) and summer $(61.7$ [48.9-76.1] nmol/l), after adjustment for age, gender, region and fasting/non-fasting blood samples. Furthermore, serum 25(OH)D concentration was higher $(P=0.041)$ in those who were fasting for blood donation $(56.8$ [42.6-72.0]) compared to those who were nonfasting at the time of donation (53.5 [38.3-73.3] nmol/l); however, $76 \%$ were fasting at time of blood donation. There was no differences in serum $25(\mathrm{OH}) \mathrm{D}$ concentration according to gender, age, or region $(P>0.2) .2 \%, 40 \%$ and $84 \%$ of this sub-sample had serum $25(\mathrm{OH}) \mathrm{D}$ levels throughout the year $<25 \mathrm{nmol} / 1<50 \mathrm{nmol} / 1$ and $<80 \mathrm{nmol} / 1$, respectively, which are internationally recognised thresholds of vitamin $\mathrm{D}$ deficiency and insufficiency. The figure shows the difference in prevalence rates of serum $25(\mathrm{OH}) \mathrm{D}<25,50$ and $80 \mathrm{nmol} / \mathrm{l}$, stratified by season.

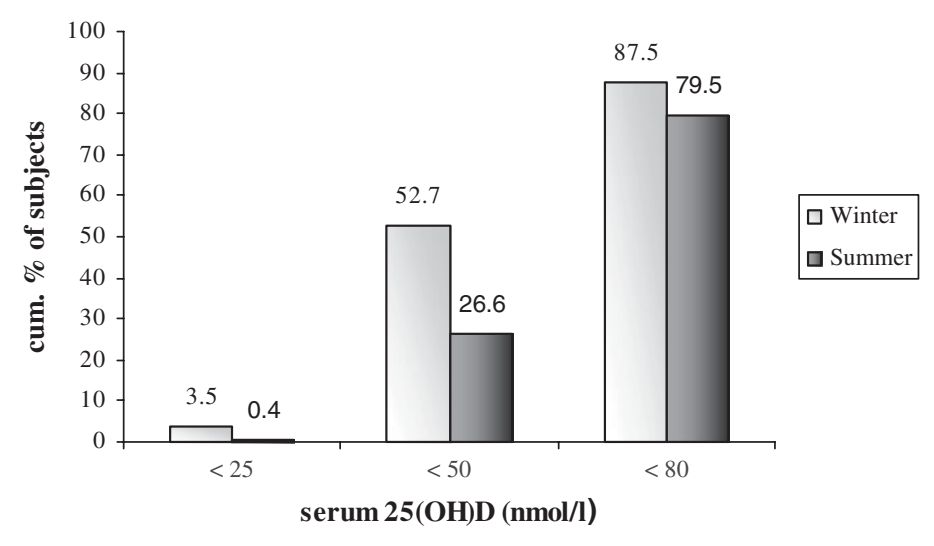

In conclusion, these data show a high prevalence of serum $25(\mathrm{OH}) \mathrm{D}$ concentrations $<50$ and $<80 \mathrm{nmol} / \mathrm{l}$ which, while still under debate, are commonly used as thresholds for vitamin D insufficiency. Severe vitamin D deficiency (serum $25(\mathrm{OH}) \mathrm{D}<25 \mathrm{nmol} / \mathrm{l})$ was not common. As expected, serum $25(\mathrm{OH}) \mathrm{D}$ concentration differed significantly according to season. It would be interesting to see if similar trends are present when the complete representative sample is analysed and then the data can be used to develop effective nutrition policies and health promotion campaigns to improve vitamin D status.

We wish to acknowledge the Irish Department of Agriculture, Fisheries and Food under the Food for Health Research Initiative (2007-2012) for their support.

1. Cashman KD, Hill TR, Lucey AJ et al. (2008) Am J Clin Nutr 88, 1535-1542.

2. Cashman KD, Wallace JM, Horigan G et al. (2009) Am J Clin Nutr 89, 1366-1374.

3. Hill TR, Flynn A, Kiely M et al. (2006) Ir Med J 99, 48-49.

4. Webb AR, Kline L \& Holick MF (1988) J Clin Endocrinol Metab 67, 373-378. 